\title{
Admen and Eve: The Bible in Contemporary Ad- vertising, by Katie B. Edwards
}

Bible in the Modern World 48 | Sheffield: Sheffield Phoenix Press, 2012 |xiv + I46 pages | ISBN: 978-I-907534-7I-3 (hardcover) $£ 50.00$

Katie Edwards's Admen and Eve: The Bible in Contemporary Advertising examines the complex relationship

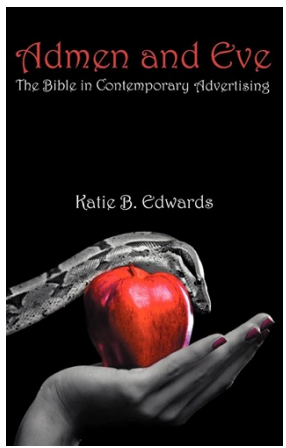
between the world of advertising and biblical characters. It is an area of study that, until recently, has received little attention from biblical scholars. Published by Sheffield Phoenix Press in 2012 as part of their Bible in the Modern World series, Admen and Eve analyzes representations of Eve in advertising from I 990 to the present-a time period Edwards characterizes as "postfeminist." The ads she examines focus on white, heterosexual representations of Adam and Eve because, she argues, the primary targets of such ads are white heterosexual female consumers (2). She concludes that Eve is an "effective sales weapon" for the products she represents (i).

After a preface and introduction, the book is divided into four chapters of varying lengths: chapter I, "Genesis 2-3: The Creation of an Icon" (23 pp); chapter 2, "The Never-Changing Face of Eve: Representations of Eve in Nineteenth Century Fin-De-Siècle Art and Twentieth Century FinDe-Siècle Advertising" (29 pp); chapter 3, "Bad Girls Sell Well: The Commodification of Eve in Postfeminist Consumerism" (63 pp); and chapter 4, "Forbidden Fruit Tastes the Sweetest: Eve Imagery in Advertising for the Desperate Housewives Franchise" ( 2 pp). As one can see, chapter 3 is almost as long as the combined length of other three chapters. This is due, in part, to the thirty-seven illustrations of various ads it contains as compared to the eight in chapter $\mathrm{I}$, the twelve in chapter 2 and the six in chapter 4 .

Edwards begins and ends chapter I ("Genesis 2-3: The Creation of an Icon") with an analysis of four ads that function as an inclusio to her critique of contemporary egalitarian readings of Genesis 2-3 (e.g., Phyllis Trible, Reuven Kimelman, Helen Schüngel-Straumann). Edwards is not persuaded by these attempts and argues that Eve is the "active character" in Genesis 3 when compared to the "passive" Adam. It is Adam who listens to the woman and therefore lets the woman have power over him (25-26). As a consequence, Edwards argues, Eve/woman's role in the transgression was 
greater than Adam's/man's role (ig). Ads that focus on the Garden's transgression pick up these "textual clues of woman's central role and guilt" (27). Why do ads prefer this type of reading? According to Edwards:

For popular cultural postfeminist interpretations of the biblical story, this vulnerability of male authority to loss of power and status through the irresistible allure of women means that the text is an ideal sales ground for products intended to increase women's sexual attractiveness and, therefore, social power- the reason that advertisements tend to portray only the moment of transgression or directly after. (28)

Indeed, Edwards finds little hope that this more traditional reading of Eve as sexual temptress will abate for consumers in the future: "After all, Eve is quite a money-maker, and so long as she can bring in the revenue she will be out there in cinemas and magazines with her trusty apple and snake to lure in consumers to take a bite of whatever product she is selling" (34).

Chapter 2 ("The Never-Changing Face of Eve: Representations of Eve in Nineteenth Century Fin-De-Siècle Art and Twentieth Century Fin-DeSiècle Advertising") compares depictions of Eve in I 890 s art with those in ads at the end of the twentieth century. Both, she argues, show an interest in "the culturally notorious image of Eve, the temptress" (35), and use her as a symbol for their idea of womanhood. The reason for this, Edwards argues, is that:

the threat of feminism is a major, if not the major, social factor underlying the birth and rebirth of the image of woman as femme fatale, and ... the proliferation of Eve images in each finde-siècle is a cultural response aimed at managing this threat by appealing to deep-rooted prejudices about the biblical figure of Eve. (36)

In spite of these similar social circumstances, the purpose of such imaging is quite different in each time period. While artists at the end of the nineteenth century see Eve as "a source of death and degeneration," postfeminist ads of the I990s, according to Edwards, see her as a source of female "empowerment" (37). Thus, for Edwards, these later ads represent Eve as the "ultimate postfeminist" who "exercises her power through her female sexuality, which is maintained or boosted through her consumer spending power" (38). 
But it is chapter 3 ("Bad Girls Sell Well: The Commodification of Eve in Postfeminist Consumerism”) that presents the high point of Edwards's argument. While conceding that contemporary advertising "rehashes old images and old stereotypes" of Eve (67), Edwards nevertheless contends that postfeminist ads sanction "women taking control of the representation of their sexuality and using it for their own financial and social gain" (68). Indeed, she insists that such a reading is consistent with Genesis itself and that advertising "makes explicit what is implicit in the text" (66). As the Eve of Gen 3 led Adam into temptation, so the Eve of postfeminist ads tantalizes female viewers with the promise of power and status. In her analysis of ad after ad, Edwards finds this message presented via a variety of tactics. Some ads select celebrities to represent Eve (e.g., Naomi Campbell, Cindy Crawford) while others present the apple as a metaphor for women's bodies. These strategies aim at persuading female viewers that consumerism is the path to power and success. But "female empowerment through self-commodification and sexualization" (86) comes at a cost. By its very nature, Edwards notes, such activity pits women against one another as each strives to be "the most successful temptress." Inevitably, only those few women who best present themselves as "attractive, young, able-bodied" and wealthy can hope to win the contest for power (84). Accordingly, Edwards shows that some recent ads have reverted to less threatening and more traditional images of Eve as a fairytale princess in search of "romance, fairytale and fantasy" (92).

Chapter 4 ("Forbidden Fruit Tastes the Sweetest: Eve Imagery in Advertising for the Desperate Housewives Franchise") is a rather odd conclusion to the book. Instead of presenting a closing argument, the chapter briefly considers how the appropriation of Eve in Desperate Housewives has ramifications for advertising the popular television program and its spin-off products. This focus is particularly confusing since the book's introduction promised that chapter 4 would discuss both Desperate Housewives and the film Twilight (I I). But Twilight receives no treatment whatsoever. Apparently there was a variant of this chapter that was not sent to press. Whether or not it will appear in a corrected edition of the book remains to be seen.

As well researched as Edwards's treatment is, readers may be left with a niggling reservation about her characterization of postfeminism. Indeed, scholars are divided as to the definition of the term. While some see it as the logical extension of feminism, others portray it as a backlash against the feminist movement. Repeatedly Edwards represents the aim of postfeminist ads as empowerment-a goal reminiscent of the feminist movement. But 
the way in which ads depict the path to that goal is, in fact, through the tired and worn stereotypes of sexual power and self-commodification. In this sense, such ads represent a type of backlash against the gains of the feminist movement not an extension of it. Nevertheless, readers will be intrigued by Edwards's analysis of the rich variety of ads that form the heart of this study.

Linda S. Schearing Valarie H. Ziegler

Gonzaga University DePauw University 